\title{
ANALOGS OF CERAMIDE THAT INHIBIT GLUCOCEREBROSIDE SYNTHETASE IN MOUSE BRAIN
}

\author{
RANGA RAO VUNNAM* and NORMAN S. RADIN \\ Mental Health Research Institute (Department of Psychiatry) and Department of Biological \\ Chemistry, University of Michigan, Ann Arbor, MI 48109 (U.S.A.)
}

Received October 9th. 1979 accepted January 5th. 1980

\begin{abstract}
In a search for potent inhibitors of glucocerebroside biosynthesis, we synthesized aromatic analogs of the enzyme's substrate, ceramide, many of which have not previously been described in the literature. Mouse brain and spleen, rat brain, and human placenta and spleen were all found to be susceptible to inhibition by a variety of compounds, although to differing extents. The most potent inhibitor was 2-decanoylamino-3-morpholino-1-phenylpropanol. The dehydro version of this compound (2-decanoylamino-3-morpholinopropiophenone) was less effective but it produced inactivation of the enzyme, probably by covalent reaction with the enzyme s active site. Examination of the various effects seen leads us to suggest that the active region of the enzyme contains four recognitional sites: an anionic moiety that may bind the glucose in activated form, an oxygen-binding region oriented toward the third carbon atom of ceramide. a narrow region that binds the alkyl chain of the fatty acid moiety, and a less narrow region that binds the hydrocarbon chain of the sphingoid base moicty.
\end{abstract}

\section{Introduction}

Glucocerebroside is a widespread sphingolipid that is both a membrane component and a precursor of more complex sphingolipids. It is synthesized from ceramide and UDP-glucose by a glucosyltransferase [1.2]. Since the lipid accumulates greatly in Gaucher's disease, due to a genetic lack of adequate $\beta$-glucosidase activity, it seemed possible to us that the symptoms of the disorder could be alleviated by treating the victims of the disease with an inhibitor of the transferase. Little is known of the functional groups in the active site of glycosyltransferases, so designing an efficient inhibitor must be done empirically.

Tests in rat brain [3] with various analogs of ceramide showed that several compounds could act as inhibitors of the glucosyltransferase. The most active inhibitors contained a benzene ring in place of the long alkene chain of sphingosine and a short chain fatty acid (decanoic) in place of the

\footnotetext{
*Present address: Becton Dickinson Immunodiagnoxtics, Mountain View Aw.. Orangchurg. NY 10162 U.S.A.
} 
normally occurring fatty acid (16-24 carbon atoms). The primary hydroxyl normally present at the terminal position of ceramide could be replaced by a hydrogen atom in the analog while retaining inhibitory activity. The secondary hydroxyl group at the C-3 position of ceramide proved to be significant: if it was in the natural (erythro) configuration with respect to the C-2 amine group, it tended to produce activity as a substrate, but if it was absent or in the threo configuration, it resulted in inhibitory activity. From these observations, it may be concluded that the $\mathrm{C}-1$ group was not important with respect to binding to the enzyme but the C- 3 substituent played a crucial role in determining whether the enzyme could act catalytically.

To extend these observations, in the hope of synthesizing even more active inhibitors, we prepared and tested additional ceramide analogs, emphasizing substituents on the $\mathrm{C}-1$ and $\mathrm{C}-3$ carbon atoms that might be more reactive.

\section{Organic syntheses}

Most starting materials were obtained from Aldrich Chemical Co., Milwaukee, WI or from Eastman Organic, or were described previously [3]. The products were shown to yield a single spot (in some cases, one or two trace spots too) by TLC on silica gel plates after spraying with a charring reagent. The spots were at approximately the expected location relative to related compounds (e.g.: longer homologs moved faster than shorter ones, ketones moved faster than the corresponding $2^{\circ}$ alcohols) and spraying them with ninhydrin or dinitrophenylhydrazine yielded the expected colors. Infrared spectra with the $\mathrm{KBr}$ pellet method revealed the expected peaks. Elemental analyses were performed by Sprang Microanalytical Laboratory and Galbraith Laboratories to confirm the structures; where necessary the compounds were recrystallized to bring them within the proper range of analytical values. Where structural assignments were in doubt, confirmation was obtained by NMR spectroscopy using tetramethylsilane as internal standard.

Note that the numbering system used for the aromatic analogs differs from that used for the sphingoid bases, as illustrated by Dt-2-amino-3hydroxypropiophenone $(I)$ in the following synthetic route:<smiles>CC#CC(=O)CNC(=O)CNC(=O)C#CC(Br)C(=O)O</smiles>

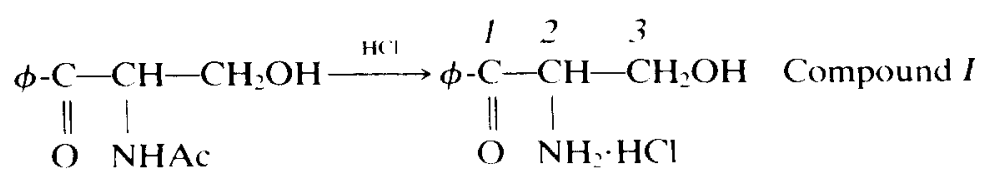




\section{A. Synthesis of 2-amino-3-hydroxypropiophenones}

Compound $I$ was prepared as the hydrochloride from 2-bromoacetophenone by amination with hexamethylenetetramine, acetylation, hydroxymethylation with formalin, and deacetylation (see above reaction sequence) [4]. $p$-Substituted derivatives of $I$ were prepared from the corresponding bromoacetophenones, which were purchased or prepared by bromination. In the case of methoxyacetophenone, bromination was done with methanolic bromine [5].

During the hydroxymethylation of 2-acetylamino- $p$-methylacetophenone, some dihydroxymethylation occurred at the C-2 position. The product (m.p. $164-165^{\circ} \mathrm{C}$ from $\mathrm{EtOAc}$ ) was hydrolyzed with $\mathrm{HCl}$ and reacylated with decanoyl chloride (amide m.p. $143-144.5^{\circ} \mathrm{C}$ from EtOAc).

These and other amine hydrochlorides were acylated with acyl chlorides in tetrahydrofuran and concd. aqueous $\mathrm{NaOAc}[6,7]$. For the synthesis of 2,3-epoxydecanoyl $I$, the free acid was coupled to the amine by a mixed anhydride method. At $-10^{\circ} \mathrm{C}, 0.13 \mathrm{ml}$ of isobutyl chloroformate was added to a stirred solution of $1 \mathrm{mmol}$ epoxydecanoic acid [8] and $0.14 \mathrm{ml}$ of $\mathrm{Et}_{3} \mathrm{~N}$ in $10 \mathrm{ml}$ of tetrahydrofuran. After $5 \mathrm{~min}$ of stirring, the mixture was added to a suspension of $1 \mathrm{mmol} I \cdot \mathrm{HCl}$ and $0.14 \mathrm{ml} \mathrm{Et}_{3} \mathrm{~N}$ in $10 \mathrm{ml}$ tetrahydrofuran, with stirring at $-10^{\circ} \mathrm{C}$. The mixture was then stirred $1 \mathrm{~h}$ at $0^{\circ} \mathrm{C}$ and $30 \mathrm{~min}$ at $22^{\circ} \mathrm{C}$. The amide was purified by partitioning between ether and $1 \%$ $\mathrm{NaHCO}_{3}$ and crystallizing from benzene/hexane.

In some syntheses, the intermediate 2 -aminoacetophenone $\cdot \mathrm{HCl}$ was acylated with a long chain acyl chloride instead of acetic anhydride, obviating the need to deacetylate and reacylate.

\section{B. Miscellaneous compounds}

$N$-Decanoyl-p-nitro- $I$ was dehydrated with pyridine/acetic anhydride [9] to produce 2-decanoylamino-p-nitroacrylophenone (m.p. $62-63^{\circ} \mathrm{C}$ from hexane).

2-Decanoylaminopropiophenone was an oil, prepared from $N$-acetyl-DLnorephedrine by oxidation of the hydroxyl group with dichromate [10], deacetylation with $\mathrm{HCl}$, and reacylation with decanoyl chloride. It was recrystallized from hexane at $-20^{\circ} \mathrm{C}$.

2-Acylaminopropiophenones bearing a tertiary amino group at the C-3 carbon atom were prepared by a Mannich reaction between a secondary amine, paraformaldehyde, and 2-acylaminoacetophenone [11].

DL-Erythro-3-phenylserine and its ethyl ester were prepared according to the method of Bolhofer [12]. The compounds gave the reported melting points. Acylation with decanoyl chloride produced the decanoylamino ester (m.p. $69^{\circ} \mathrm{C}$ from benzene/hexane) and the free acid (m.p. $114-115^{\circ} \mathrm{C}$ ). Treatment of the amido ester for 2 days with ethanol saturated at room temperature with ammonia yielded the carboxamide in $65 \%$ yield, m.p. $177^{\circ} \mathrm{C}$ from methanol. The decanoylamino ester was converted also to the 
hydrazide by stirring $1 \mathrm{~g}$ of ester with $0.5 \mathrm{ml}$ of hydrazine hydrate in $5 \mathrm{ml}$ of methanol for $4 \mathrm{~h}$. The product was recrystallized from boiling methanol: m.p. $229-230^{\circ} \mathrm{C}$. Like the other inhibitors, it was stored in chloroform/methanol, but a little $\mathrm{HCl}$ had to be added to increase its solubility. The threo isomer of DL-phenylserine was purchased from U.S. Biochemicals Corp. and converted to the $N$-decanoyl ethyl ester (m.p. $64-65^{\circ} \mathrm{C}$ from benzene/hexane).

$N$-Bromoacetyl sphingosine, m.p. $84-85^{\circ} \mathrm{C}$, was prepared from equimolar quantities of bromoacetyl bromide and $\mathrm{D}$-sphingosine by the $\mathrm{NaOAC}$ method described above. It was purified by silica gel chromatography using chloroform/methanol $99: 1$ and $99: 2$.

$\mathrm{N}$-Decylthiocarbamyl norephedrine $\quad\left[\mathrm{C}_{10} \mathrm{H}_{2 !}-\mathrm{NH}-\mathrm{C}(=\mathrm{S})-\mathrm{NH}-\right.$ $\left.\mathrm{CH}\left(\mathrm{CH}_{3}\right)-\mathrm{CHOH}-\mathrm{C}_{6} \mathrm{H}_{5}\right]$ was made by refluxing equimolar amounts of DL-norephedrine and $n$-decylisothiocyanate in EtOH for $6 \mathrm{~h}$. The solution was evaporated to dryness and the residue recrystallized.

The tables in the Results section give additional data on the m.p. and solvent of recrystallization for the individual compounds.

\section{Enzyme assays}

Most assays for glucosyltransferase were run with lyophilized brain homogenates from 16 day male mice, incubated at $37^{\circ} \mathrm{C}$ for 90 min [3] with $0.2 \mu \mathrm{mol}$ of $N$-octanoyl sphingosine or DDS ( $N$-dodecanoyl-Dl-decasphinganine or lauroyl erythro-2-amino-1,3-decanediol) as glucose acceptors $[x]$. The compounds tested as inhibitors (generally as $(0.3 \mathrm{mM}$ ) were evaporated to dryness from solution in the incubation tube with the lipoidal substrate before adding the lyophilized tissue in benzene and evaporating off the solvent. (Because of the toxicity of benzene, the processing must be done in a good hood. However recent work has shown that benzene can be replaced by cyclohexane.) The remaining incubation components (dithioerythritol. Tris-Cl pH 7.4 or 7.8 , ATP, EDTA, $\mathrm{Mg}^{2+}$, and $\left[{ }^{3} \mathrm{H}\right] \mathrm{UDP}$-glucose) were then added in water. In some experiments, the lipoidal substrate was added in liposomal form [8]. The cerebroside formed in the incubation was isolated by partitioning between chloroform, methanol, and water. This step [3] was simplified by omitting the filtration step for removal of brain nonlipids. The lipid thus obtained was assayed by liquid scintillation in a water-containing solvent.

\section{Results}

Amides of 2-amino-3-hydroxypropiophenone (I)

A comparison of different acyl derivatives of $I$, tested at $0.3 \mathrm{mM}$ (Table $\mathrm{I}$ ). 
showed that the decanoyl compound (RV-49) was the most effective and that shorter and longer homologs were markedly less effective. This kind of dependency on chain length has been noted before with several series of compounds tested with enzymes of sphingolipid metabolism. Slightly modifying the 2,3-position of the decanoyl residue did not affect, or enhanced the inhibitory power of the compound. Similar results were obtained with rat brain glucosyltransferase, using natural ceramides as substrate.

Larger substituents on the fatty alkyl chain (the last 5 lines of Table I) reduced the effectiveness of the basic structure. However the last compound, in which the bromine atom was far from the amide link, was relatively active, suggesting that the acyl recognition site in the enzyme loses its specificity as the distance from the active site increases. Not shown in the table are the rather inert halogen derivatives of $I: N$-chloroacetyl (m.p. $128-129^{\circ} \mathrm{C}$ ), dichloroacetyl (m.p. $134-136^{\circ} \mathrm{C}$ ), and 3-bromopropionyl (m.p. $\left.83-84^{\circ} \mathrm{C}\right)$.

\section{TABLE I}

$N$-ACYL DERIVATIVES OF 2-AMINO-3-HYDROXYPROPIOPHENONE ( $I$ ) AS INHIBITORS OF GLU COSYLTRANSFERASE IN MOUSE BRAIN

Assay run with $1 \mathrm{mg}$ of mouse brain powder, $0.2 \mu$ mole DDS. Tris-C1 (pH 7.4). UDP$\left[{ }^{3} \mathrm{H}\right]$ glucose, and other factors (see text), incubated $90 \mathrm{~min}$ at $37^{\circ} \mathrm{C}$. Controls synthesized $1.69 \mathrm{nmol}$ of glucocerebroside. Inhibitors were tested at $0.3 \mathrm{mM}$. The melting points were obtained after recrystallizing the samples from EtOAc benzene, hexane, or mixtures of these solvents.

\begin{tabular}{lcl}
\hline$N$-Acyl group & $\begin{array}{l}\text { M.p. } \\
(\%)\end{array}$ & $\begin{array}{l}\text { Inhibition } \\
(\% \text { of control) }\end{array}$ \\
\hline Acetyl & $11+-117$ & 11 \\
Hexanoyl & $6(1-61$ & 22 \\
Octanoyl & 84 & 44 \\
Decanoyl (RV-49) & $7+-75$ & 70 \\
Dodecanoyl & $7(1-72$ & 60 \\
Tetradecanoyl & $84-85$ & 4.3 \\
Hexadecanoyl & $90-91$ & 41 \\
& $94.5-95.5$ & 79 \\
2-Decenoyl & $9(1)-92$ & 73 \\
2.3-Epoxydecanoyl & $119-119.5$ & 35 \\
& 148 & 28 \\
Cinnamoyl & $134-135$ & 36 \\
4-Fluorosulfonylbenzoyl & $99-10(0)$ & 36 \\
Bromoacetyl & $9(1-91$ & 50 \\
8-Bromooctanoyl & & \\
12-Bromododecanoyl & & \\
\hline
\end{tabular}


The presence of small substituents (methyl and methoxyl) at the $p$ position of the phenyl group had no effect on the inhibitory power of RV-49 (decanoyl I) but larger groups $(\mathrm{Cl}, \mathrm{Br}$, nitro) reduced the effectiveness (Table II). The 2-hydroxymethyl derivative of the first compound in this table was a moderately effective inhibitor $(43 \%)$ but less so than the unsubstituted compound $(68 \%)$. It is interesting that the binding site of the enzyme can accommodate the relatively bulky side group, but the resultant effect does not look useful.

Substitution of the hydroxyl group in RV-49 by hydrogen (producing $N$-decanoylaminopropiophenone) reduced its inhibitory power only slightly. This extends our previous observation that the primary $\mathrm{OH}$ group is not essential for inhibitory activity. The unsaturated derivative of a related compound (2-decanoylamino-p-nitroacrylophenone), which also had no terminal hydroxyl group, was even more active than RV-49 (see Table V later).

Enzyme inactivation by a $\beta$-keto alcohol analog

We thought that the carbonyl group in the above mentioned inhibitors might bind to the enzyme in a covalent manner, possibly by forming a Schiff base or an adduct with an active amine group (from lysine or histidine) at

\section{TABLE II}

EFFECT OF $p$-SUBSTITUENTS ON THE PHENYL GROUP OF $N$-DECANOYL-I (RV49) IN CERAMIDE:GLUCOSYLTRANSFERASE INHIBITION

Melting points in ${ }^{\circ} \mathrm{C}$. Assay conditions as in Table $\mathrm{I}$. The percent inhibitions refer to tests of the decanoylamino derivatives.

\begin{tabular}{lllll}
$p$-Substituent & $\begin{array}{l}\text { M.p. of free } \\
\text { base } \cdot \mathrm{HCl}\end{array}$ & $\begin{array}{l}\text { M.p. of acetyl } \\
\text { amine }\end{array}$ & $\begin{array}{l}\text { M.p. of decanoyl } \\
\text { amine }\end{array}$ & $\begin{array}{l}\text { Inhibition } \\
(\%)\end{array}$ \\
\hline Methyl & $169-171$ & $123-124^{\mathrm{a}}$ & $78-79$ & 68 \\
Methoxy & $183-184$ & $120-122^{\mathrm{b}}$ & $83-84$ & 71 \\
Chloro & $194-197$ & $125-126^{\mathrm{c}}$ & $9(-92$ & 46 \\
Bromo & 200 & $145-147^{\mathrm{d}}$ & $92-94$ & 47 \\
Nitro & $179-180$ & $164-165^{\mathrm{c}}$ & $95-96$ & 50 \\
\hline
\end{tabular}

${ }^{\mathrm{a}}$ Reported m.p. $121^{\circ} \mathrm{C}[15]$.

${ }^{b}$ Reported m.p. $120-122^{\circ} \mathrm{C}[16]$.

'Reported m.p. 125-126 ${ }^{\circ} \mathrm{C}$ [17].

${ }^{d}$ Reported m.p. $145-147^{\circ} \mathrm{C}$ [17].

${ }^{\mathrm{e}}$ Reported m.p. $164-166^{\circ} \mathrm{C}$, dec. [4]. 
the enzyme's active site. A time study with $0.3 \mathrm{mM}$ compound RV-49 (Fig. 1) showed that the keto alcohol produced a gradually increasing degree of inhibition and the transferase was completely inactive after about $60 \mathrm{~min}$ of exposure to the ketone (as shown by failure of the system to synthesize additional cerebroside). This type of gradual inactivation had previously been observed with a ceramide analog containing the 2,3-epoxydecanoyl group [3] and it is possible that both compounds reacted covalently with the same reactive group in the enzyme's active site.

The other curve in Fig. 1 was obtained with $1 / 2$ the concentration of inhibitor $(0.15 \mathrm{mM})$, in which case complete inactivation of the enzyme was not observed. This phenomenon, which was seen with other inactivating inhibitors of the propiophenone series, may be due to gradual loss of inhibitor by a competing chemical reaction with other components of the system.

\section{Acyl derivatives of norephedrine}

Our previous study of amides derived from erythro-DL-1-phenyl-2-aminopropanol [3] had shown that the decanoyl compound was a strong inhibitor. Additional amides were prepared (Table III) and again the simple, 10-

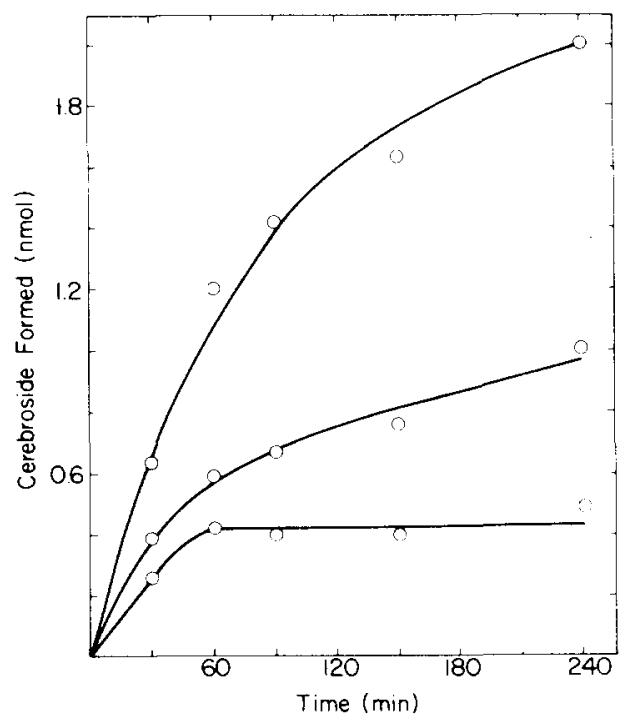

Fig. 1. Amount of cerebroside formed as a function of time in the presence of RV-49 (2-decanoylamino-3-hydroxypropiophenone). Each incubation tube contained $1 \mathrm{mg}$ of mouse brain powder, $0.2 \mu \mathrm{mol}$ of $\mathrm{N}$-dodecanoyl decasphinganine, labeled UDP-glucose. Tris- $\mathrm{Cl}(\mathrm{pH}$ 7.4), EDTA, dithioerythritol, $\mathrm{MgCl}_{2}$, and ATP. The top curve was obtained from control tubes, the middle curve was obtained from tubes containing $0.15 \mathrm{mM}$ inhibitor, and the bottom curve, from $0.3 \mathrm{mM}$ inhibitor. Each point is the average derived from three incubation tubes. 


\section{TABLE III}

INHIBITION OF MOUSE BRAIN GLUCOSYLTRANSFERASE BY AMIDES OF NOREPHEDRINE (ERYTHRO-DL-1-PHENYL-2-AMINO-1-PROPANOL)

Assays run as in Table I.

\begin{tabular}{llll}
\hline N-Acyl group & $\begin{array}{l}\text { M.p. } \\
\left({ }^{\circ} \mathrm{C}\right)\end{array}$ & $\begin{array}{l}\text { Crystallization } \\
\text { solvent }\end{array}$ & $\begin{array}{l}\text { Inhibition } \\
(\%)\end{array}$ \\
\hline Decanoyl & $69-70$ & hexanc & $\times 2$ \\
2.3 -Epoxydecanoyl & $94-95$ & henzene/hexanc & 72 \\
Oleoyl & $53-54$ & hexane & 49 \\
Phenylpropynoyl & 140 & iso-PrOH & 24 \\
Bromoacetyl & $10,10-114$ & benzene & 16 \\
Dichloroacetyl & 92 & henzene/hexanc & 11 \\
m-Fluorosulfonylbenzoyl & $109-111$ & henzene & 11 \\
P-Fluorosulfonylbenzoyl & 162 & EtoAc/hexane & 18 \\
$N$-Decylthiocarbamyl & 105 & benzene & 6.3 \\
\hline
\end{tabular}

carbon acid was found to be the most active. Evidently the binding site for the acyl group cannot readily accomodate bulkier groups. The decylthiocarbamyl derivative resembles the decanoyl moiety but it is a bit larger because of the sulfur atom. This compound was not much less inhibitory and it is possible that further study of the compound would show that it reacts covalently through the sulfur atom.

\section{3-Amino derivatives of 2-decanoylaminopropiophenone}

The promising action of the 3-hydroxy compounds (Table I) was studied further by preparing amine analogs. We knew [3] that a secondary amino group near the terminal carbon (actually at the $\mathrm{C}-2$ position) did not affect the degree of inhibition. Moreover it was known that $\beta$-amino ketones are relatively reactive, generating reactive products which might form covalent derivatives with the glucosyltransferase.

We therefore synthesized [11] some tertiary amine derivatives of 2decanoylaminopropiophenone from morpholine (RV-378). 4-methylpiperatine (m.p. $135-137^{\circ} \mathrm{C}$ ), $N$-methyl-aminoethanol (m.p. $91-93^{\circ} \mathrm{C}$ ), and piperidine (RV-471). The first three compounds were crystallized as the hydrochlorides and the last as the salt of $p$-toluenesulfonic acid, which was itself inert in the transferase assay. The second and third amines were less pure and were not checked by elemental analyses or studied in depth. The amino ketones were unstable in silica gel columns when chromatographed with neutral solvents, and TLC with neutral or ammoniacal solvents produced streaking. However good TLC plates were obtained with chloro- 
form/methanol/acetic acid $(90: 5: 10)$ the $R_{\mathrm{F}}$ values being $0.68,0.26,0.15$, and 0.55 , respectively.

Tested at $0.3 \mathrm{mM}$, the amines produced 86 to $95 \%$ inhibition. The acetyl homolog of RV-378 yielded only $14 \%$ inhibition, showing here too the importance of chain length in the acyl group.

Increasing the concentration of the lipoidal substrate, octanoyl sphingosine, did not protect the enzyme against inhibition by RV-378, the morpholino ketone (Table IV). It did, however, produce distinct protection against the weaker inhibitors, decanoyl norephedrine and RV-49. Note that RV-378 was tested at a lower concentration than the other two and that the usual concentration of octanoyl sphingosine in our assay system is $1 \mathrm{mM}$. These competitive effects support the expectation that the ceramide analogs bind to the ceramide-binding site and that the amino ketone binds somewhat more firmly.

Reduction of the ketone group in RV-378 produced a mixture of erythro and threo isomers (RV-538) that proved to be an even more effective, very potent inhibitor. However the reduced amino ketone affected the enzyme by a different mechanism (Fig. 2). Except for the first time point, the hydroxy morpholino compound produced a constant degree of inhibition, consistent with the idea that it is a reversible inhibitor. The ketone, on the other hand, behaved like RV-49 (Fig. 1) and simply inactivated the enzyme. At $0.15 \mathrm{mM}$ RV-378, the enzyme became inactivated during the first $80 \mathrm{~min}$ of contact.

In the above experiment we used wet brain homogenate and the substrate (DDS) was added in liposomal form [8]. The effectiveness of RV-378 in this incubation system was lower than in the usual incubations, in which the

\section{TABLE IV}

PROTECTION OF MOUSE BRAIN GLUCOSYLTRANSFERASE BY SUBSTRATE (OCTANOYL SPHINGOSINE)

"Dec" is the decanoyl group. The first two inhibitors were tested at $0.15 \mathrm{mM}$ and the third, at $75 \mu \mathrm{M}$. The amount of cerebroside formed is in the units, $\mathrm{nmol} / 90 \mathrm{~min}$.

\begin{tabular}{|c|c|c|c|c|}
\hline \multirow[t]{2}{*}{ Inhibitor } & \multicolumn{2}{|c|}{$\begin{array}{l}\text { Cerebroside } \\
\text { synthesized }\end{array}$} & \multicolumn{2}{|l|}{$\begin{array}{l}\text { Inhibition } \\
(\%)\end{array}$} \\
\hline & $0.5 \mathrm{mM}$ & $3 \mathrm{mM}$ & $0.5 \mathrm{mM}$ & $3 \mathrm{mM}$ \\
\hline Controls & 1.93 & 2.22 & - & - \\
\hline Phenyl- $\mathrm{CH}(\mathrm{OH})-\mathrm{CH}(\mathrm{NHDec})-\mathrm{CH}_{3}$ & 0.86 & 1.51 & 56 & 32 \\
\hline Phenyl- $\mathrm{C}(=\mathrm{O})-\mathrm{CH}(\mathrm{NHDec})-\mathrm{CH}_{2} \mathrm{OH}$ & 0.93 & 1.68 & 52 & 24 \\
\hline Phenyl- $\mathrm{C}(=\mathrm{O})-\mathrm{CH}(\mathrm{NHDec})-\mathrm{CH}_{2}-$ morpholine & 1.31 & 1.57 & 32 & 29 \\
\hline
\end{tabular}




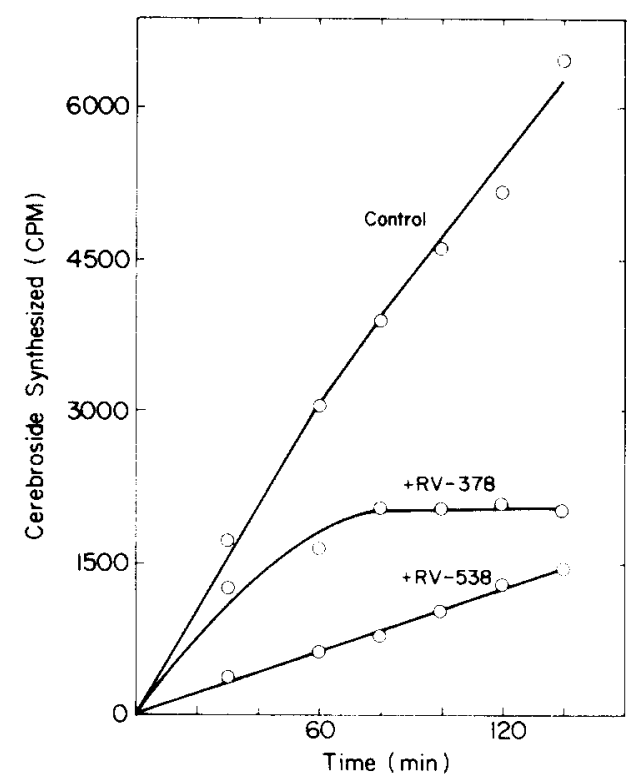

Fig. 2. Amount of glucocerebroside formed in the presence of two related morpholino decanoylamino derivatives. Each incubation tube contained $6 \mathrm{mg}$ of homogenized mouse brain, the factors listed in the legend to Fig. 1 , and $0.2 \mu \mathrm{mol}$ of dodecanoyl decasphinganine in liposomes formed with $565 \mu \mathrm{g}$ of lecithin and $100 \mu \mathrm{g}$ of cerebroside sulfate, Na salt. The topmost curve was derived from control incubations, the middle curve was obtained with $0.15 \mathrm{mM}$ 2-decanoylamino-3-morpholinopropiophenone, and the lowest curve was obtained with its reduction product, $0.15 \mathrm{mM}$ 2-decanoylamino-3-morpholino-1-phenylpropanol.

inhibitor made contact with the lyophilized tissue while in benzene. Evidently the latter condition produced better contact between enzyme and inhibitor. The difference in effectiveness between the two incubation conditions was even greater when less soluble inhibitors were tested.

\section{Tests at lower concentrations}

Many of the transferase inhibitors were tested at concentrations below $0.3 \mathrm{mM}$ to clarify their relative degrees of effectiveness (Table $\mathrm{V}$ ). The strongest inhibitors at $0.15 \mathrm{mM}$ were RV-441 (decanoyl norephedrine), $\mathrm{RV}-378, \mathrm{RV}-471$, and RV-538. Tested at $37.5 \mu \mathrm{M}$, the first two of these were much less potent but the piperidino ketone and reduced RV-378 were still very active. It is curious that some inhibitors, at the lowest concentration tested, actually seemed to stimulate the enzyme.

Not shown is a test with mouse spleen (1 $\mathrm{mg}$ of lyophilized tissue) and DDS, which yielded $1.27 \mathrm{nmol}$ of cerebroside in $90 \mathrm{~min}$. The effectiveness of the various inhibitors was similar to that seen with brain, although some inhibitors were more effective in one organ than in the other. This may 
TABLE V

INHIBITION OF GLUCOSYLTRANSFERASE BY CERAMIDE ANALOGS TESTED AT LOWER CONCENTRATIONS (150) AND $37.5 \mu \mathrm{M}$ )

Assays run with mouse brain powder and DDS as described in text. "Dec" = the decanoyl group. A plus sign indicates increased glucolipid formation.

\begin{tabular}{|c|c|c|}
\hline \multirow[b]{2}{*}{ Inhibitor } & \multicolumn{2}{|c|}{$\begin{array}{l}\text { Inhibition } \\
\text { ( } \% \text { of control) }\end{array}$} \\
\hline & $150 \mu \mathrm{M}$ & $37.5 \mu \mathrm{M}$ \\
\hline Phenyl- $\mathrm{C}(=\mathrm{O})-\mathrm{CH}(\mathrm{NHDec})-\mathrm{CH}_{2} \mathrm{OH}(\mathrm{RV}-49)$ & 30 & +15 \\
\hline$p-\mathrm{CH}_{3} \mathrm{O}-$ phenyl- $\mathrm{C}(=\mathrm{O})-\mathrm{CH}(\mathrm{NHDec})-\mathrm{CH}_{2} \mathrm{OH}$ & 28 & +24 \\
\hline Phenyl $-\mathrm{C}(=\mathrm{O})-\mathrm{CH}(\mathrm{NHDec})-\mathrm{CH}_{3}$ & 24 & +17 \\
\hline$p$-Nitro-phenyl- $\mathrm{C}(=\mathrm{O})-\mathrm{C}(\mathrm{NHDec})=\mathrm{CH}_{2}$ & 40 & +10 \\
\hline Phenyl-CH(OH)- $\mathrm{CH}(\mathrm{NHDec})-\mathrm{CH}_{3}(\mathrm{RV}-441)$ & 6.5 & 15 \\
\hline Phenyl-C $(=\mathrm{O})-\mathrm{CH}(\mathrm{NHDec})-\mathrm{CH}_{2}-$ morpholine (RV-378) & 72 & 34 \\
\hline Phenyl- $\mathrm{CH}(\mathrm{OH})-\mathrm{CH}(\mathrm{NHDec})-\mathrm{CH}_{2}-$ morpholine $(\mathrm{RV}-538)$ & 94 & 84 \\
\hline Phenyl-C $=\mathrm{O})-\mathrm{CH}(\mathrm{NHDec})-\mathrm{CH}_{2}-$ piperidine $(\mathrm{RV}-471)$ & 89 & 63 \\
\hline Phenyl- $-\mathrm{CH}(\mathrm{OH})-\mathrm{CH}(\mathrm{NHDec})-\mathrm{COOEt}$ & 50 & 6 \\
\hline $\mathrm{N}$-Bromoacetyl sphingosine & 49 & 9 \\
\hline
\end{tabular}

\section{TABLE VI}

\section{INHIBITION OF HUMAN TISSUE GLUCOCEREBROSIDE BIOSYNTHESIS, IN PLACENTA AND GAUCHER SPLEEN}

Assays were run with $1.5 \mathrm{mg}$ of lyophilized tissue with DDS as substrate, at $\mathrm{pH} 7.8$ for $90 \mathrm{~min}$. (This weight falls within the linear region of activity versus tissue weight.) The control activities were $0.81 \mathrm{nmol}$ cerebroside formed by spleen and $0.54 \mathrm{nmol}$ formed by placenta. For structures of inhibitors see Table $\mathrm{V}(\mathrm{PP}=$ propiophenone; $\mathrm{PL}=$ phenylpropanol $)$.

\begin{tabular}{|c|c|c|}
\hline \multirow[b]{2}{*}{ Inhibitor } & \multicolumn{2}{|c|}{ Inhibition $(\%)$} \\
\hline & Placenta & Spleen \\
\hline RV-378 [decanoylamino-morpholino-PP] $(150 \mu \mathrm{M})$ & 29 & 71 \\
\hline RV-378 [decanoylamino-morpholino-PP] $(37.5 \mu \mathrm{M})$ & 11 & 22 \\
\hline RV-471 [decanoylamino-morpholino-PL] $(150 \mu \mathrm{M})$ & 26 & 76 \\
\hline RV-471 [decanoylamino-morpholino-PL] $(37.5 \mu \mathrm{M})$ & 27 & 45 \\
\hline RV-49 [decanoylamino-hydroxy-PP] $(300 \mu \mathrm{M})$ & 38 & 48 \\
\hline RV-49 [decanoylamino-hydroxy-PP) $(150 \mu \mathrm{M})$ & 33 & 46 \\
\hline RV-441 [decanoylamino-PL] $(300 \mu \mathrm{M})$ & 37 & 63 \\
\hline RV-441 [decanoylamino-PL] $(150 \mu \mathrm{M})$ & 38 & 46 \\
\hline
\end{tabular}


TABLE VII

$N$-DECANOYL ERYTHRO-PHENYLSERINE DERIVATIVES AS INHIBITORS OF MOUSE BRAIN GLUCOSYLTRANSFERASE

Assayed with mouse brain powder and DDS as in the text.

\begin{tabular}{|c|c|c|c|}
\hline $\mathrm{R}$ group & $\begin{array}{l}\mathrm{C}_{\mathrm{O}} \mathrm{H}-\mathrm{CH}-\mathrm{CH} \\
\underset{\mathrm{OH}}{\mathrm{NH}} \\
\text { Crystallization } \\
\text { solvent }\end{array}$ & $\begin{array}{l}\mathrm{H}_{1,1} \\
\mathrm{M}_{\mathrm{p}} \\
(\mathrm{OC})\end{array}$ & $\begin{array}{l}\text { Inhibition } \\
(\%)\end{array}$ \\
\hline $\mathrm{COOH}$ & benzene & $11+115$ & 34 \\
\hline COOEt & benzene/hexane & 69 & 74 \\
\hline $\mathrm{CONH}_{2}$ & methanol & 177 & 14 \\
\hline $\mathrm{CONHNH}_{2}$ & methanol & 2311 & 8 \\
\hline
\end{tabular}

indicate the existence of different types of glucosyltransferase in the two organs; we had previously seen other differences between the glucosyltransferases of mouse liver and brain [8].

Since the primary goal of this project was to develop inhibitors that were effective in human (Gaucher) tissues, we examined some of the compounds with human placenta and Gaucher spleen (Table VI). All showed promising activity, with greater effectiveness in the spleen. As noted above, such differences could indicate that the two tissues contain transferases with different properties.

\section{Derivatives of $\mathrm{N}$-decanoyl-DL-erythro-3-phenylserine}

The free erythro acid showed some inhibitory activity but the amide and hydrazide were rather inert (Table VII). The ethyl ester, however, was quite a strong inhibitor. Unexpectedly, the $N$-decanoyl derivative of the threo amino acid, ethyl ester, was a little less effective than the erythro isomer.

\section{Discussion}

The experiments described above contribute additional information about the nature of the active site in ceramide:UDP-glucose glucosyltransferase. Ceramide analogs seem to bind to the active site that normally binds the lipoidal substrate, ceramide. Replacement of the primary $\mathrm{OH}$ of the ceramide analogs with a hydrogen atom or larger group does not appreciably block binding. When the larger group is an amine, the analog's effectiveness increases considerably, suggesting that there is an anionic group in the active site. This could be a thiol, carboxyl, or phosphate group, any of which could form a glucoside of high energy by reaction with UDP-glucose, and then pass on the sugar residue to ceramide. 
Supporting the idea of an anionic site is the observation (Table VII) that decanoyl phenylserine (the free acid) was a weak inhibitor while its ethyl ester was a strong one. One would expect that an anionic site would repel a negatively-charged analog of ceramide but not a nonionic analog.

The hydroxyl or carbonyl group in the $\mathrm{C}-3$ position of ceramide $(\mathrm{C}-1$ of the aromatic analogs) was also of high significance to the enzyme's binding site. Reduction of the carbonyl group to a hydroxyl considerably enhanced the compound's potency, both in the case of the nonionic RV-49 and the cationic RV-378. Evidently there is a region close to the active site of the enzyme that can form a strong bond with the hydroxyl group. However the ketonic oxygen seems to have a particular role in producing inactivation of the enzyme.

One explanation for this role is that the keto amine or alcohol binds to the active site, then a $\beta$-elimination reaction expels the $\mathrm{C}-3$ group and the $\mathrm{C}-2$ hydrogen, forming water or a secondary amine (e.g.: morpholine) and 2-decanoylaminoacrylophenone. A Michael addition reaction could then occur in which a nucleophilic group in the active site would add to the double bond in the acrylophenone. The proposed nucleophilic group could be the postulated anionic group $\left(\mathrm{SH}, \mathrm{COOH}, \mathrm{PO}_{4}\right.$ ) or an amine (lysine) or imidazole (histidine). However, the latter groups would probably have a positive charge at the $\mathrm{pH}$ used in our incubations and would be expected to repel the highly effective cationic inhibitors.

The above hypothesis explains why RV-49 is less potent than RV-378, since $\beta$-keto alcohols are more stable at neutral $\mathrm{pH}$ than $\beta$-keto amines. The ketone lacking a polar group at the 3-position (decanoylaminopropiophenone) was even less effective and did not produce complete enzyme inactivation even when incubated for a long time. This compound would not be expected to spontaneously form an acrylophenone.

Support for the proposed elimination reaction comes from the work of Schönenberger et al. [13], who showed that aromatic $\beta$-amino ketones undergo spontaneous elimination of the amine moiety in neutral solution, with formation of the acrylophenone. A wide range of biological activities was exhibited by the compounds studied and the authors proposed a mechanism of action similar to the one above.

These authors also observed a second reaction with the aromatic amino ketones, a hydrolytic cleavage in which formaldehyde and the amine were formed (a reversal of the organic synthesis). Formaldehyde, like acrylophenones, is highly reactive and could inactivate the enzyme. Either reaction might be catalyzed by the enzyme, making this a possible example of 'active-site-directed irreversible enzyme inhibition' [14].

The relative bulkiness of the amine group in RV-378 and related compounds may act to enhance binding to the enzyme because of the steric resemblance to the glucose residue that becomes attached to that position in the normal mode of enzyme reaction. 
One might postulate that the ketonic enzyme inhibitors act, not by forming a covalent linkage with the enzyme's active site, but by binding somewhere else, deforming the enzyme molecule sufficiently to make it thermally unstable. However, in several instances the reduced (hydroxylic) analog was more effective than the original ketone, yet it did not produce inactivation (Fig. 2).

The most active compound we made, RV-538, is probably more active than it seems since it contains the erythro form, which is probably less potent than the threo form. If the compound were to be administered in vivo, part of it might be oxidized enzymatically to the ketone (RV-378), thus giving it dual modes of action. Experiments in progress have shown that RV-378 is active in mice, producing inactivation of liver glucosyltransferase. It is also a relatively effective inhibitor of monoamine oxidase in mice [11], which complicates the therapeutic implications.

\section{Acknowledgements}

This work was supported by NIH grants NS-03192 and HD-07406. We are indebted to Inez Mason, Pauline Arisumi, Carol Black, and Dan del Vecchio for laboratory assistance and to Drs. Ruth Heyn and K.M.J. Mennon for their vital help in obtaining human tissues.

\section{References}

1 S. Basu, B. Kaufman and S. Roseman, J. Biol. Chem., 248 (1973) 1388.

2 A. Brenkert and N.S. Radin, Brain Res., 36 (1972) 183.

3 K.R. Warren, R.S. Misra, R.C. Arora and N.S. Radin, J. Neurochem., 26 (1976) 1063.

4 L.M. Long and H.D. Troutman, J. Am. Chem. Soc., 71 (1949) 2473.

5 British Patent No. 607,538 (1948).

6 D. Shapiro and H.M. Flowers, J. Am. Chem. Soc., 83 (1961) 3327.

7 N.S. Radin, Methods Enzymol, 28 (1972) 300.

8 R.R. Vunnam and N.S. Radin, Biochim. Biophys. Acta, 573 (1979) 73.

9 J. Kollonitsch and A. Hajos, Acta Chim. Acad. Sci. Hung., 18 (1955) 271.

10 R.C. Gaver and C.C. Sweeley, J. Am. Chem. Soc., 88 (1966) 3643.

11 R.R. Vunnam, D. Bond, R.A. Schatz, N.S. Radin and N. Narasimhachari, J. Neurochem.. 34 (1980) 410 .

12 W.A. Bolhofer, J. Am. Chem. Soc., 74 (1952) 5459.

13 H. Schönenberger, T. Bastug, L. Bindl, A. Adam, D. Adam, A. Petter and W. Zwez, Pharm. Acta Helv., 44 (1969) 691.

14 B.R. Baker, Design of Active-Site-Directed Irreversible Enzyme Inhibitors, John Wiley \& Sons Inc., New York, 1967.

15 Ng.Ph. Buu-Hoi, Ng.D. Xuong and Ng.H. Khoi, J. Chem. Soc. (1951) 255.

16 M.C. Rebstock and E.L. Pfeiffer, J. Am. Chem. Soc., 74 (1952) 3207.

17 L.L. Bambas, H.D. Troutman and L.M. Long, J. Am. Chem. Soc., 72 (1950) 4445. 